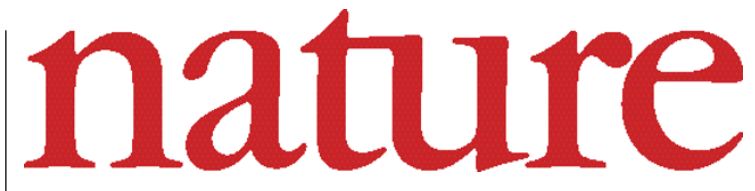

2 January 2003 Volume 421 Issue no 6918

\title{
Nature in 2003
}

This year sees Nature getting up close and personal with researchers, thanks to a new series and a territorial expansion. Another important innovation is a policy that allows authors to retain copyright.

O ne of the world's longest-running radio series is the BBC's Desert Island Discs, in which celebrities of the day are invited to select the eight recordings that they'd prefer to be marooned with, as well as talk about their favourite subject: themselves. Not immune to the appeal of this format, we are this week launching our own interview series, Lifelines (see page 23), in which working scientists (not necessarily celebrities) are provoked into taking a sidelong, irreverent and sometimes profound look at their own lives and tastes. On the grounds that those who do not seek public office are the best qualified for the job, unsolicited contributions to this section will not be considered. (For this we can cite some kind of precedent. Herbert Morrison, a British cabinet minister of an earlier generation, desired nothing more than to appear on Desert Island Discs. His desire was so great that he carried a list of his eight favourite recordings in his pocketbook, just in case he got the call. He never did.)

More developments in content are on their way. Later this month, readers will encounter an enhancement of our News and Views section, intended to increase its diversity. And later in the year there will be a new series devoted to the influences of science on the arts.

Another development is geographic. Nature already has editorial staff in London, Munich, Paris, Washington DC, San Francisco, San Diego and Tokyo. But if one considers the world's outstanding centres of scientific activity, there is a glaring omission in that list - a city which, despite recent stockmarket upheavals, is experiencing a series of new activities in traditional university departments, multidisciplinary research centres, technological spin-offs and industrial research laboratories. Accordingly, Nature and its family of research journals will be represented in Boston, with the opening of a new office there.

These editorial bases, coupled with the New York base of six of our eight sister research journals (one of which, Nature Genetics, has been celebrating its tenth anniversary year), give us the benefits of proximity and, through closer engagement, a greater sense of kinship in pursuing the interests and needs of researchers, whether as authors or readers.
New services to authors will be announced before long, but perhaps the most significant development on this front is that Nature and all other journals published by the Nature Publishing Group (NPG) have introduced a new policy in relation to copyright. No longer do we require authors of papers to sign away their copyright. Instead, we now ask authors to grant NPG the exclusive licence to publish the paper in all media throughout the world, to translate it into other languages, and to adapt it or license it to others. (If all co-authors are US government employees, slightly different arrangements apply.)

Ownership of copyright remains with the authors. Provided that, when reproducing their contribution or extracts from it, the authors acknowledge the original publication in Nature or other NPG journal, they may reproduce the paper in any printed volume of which they are the authors. Furthermore, they and any academic institution where they work at the time may reproduce the paper without payment for the purpose of course teaching.

Authors may also post a copy of their paper on their own website once the printed edition has been published, provided that they also provide a link from the contribution to Nature's website. "Their own" refers to any site devoted to them, whether owned by them or by a not-for-profit employer. However, it does not mean open archival websites, such as those that host collections of articles by an institution's researchers, which would amount to a breach of our licence.

This policy is being applied retrospectively. Hundreds of thousands of scientists are authors of papers covered by copyright agreements that are still in force, and we cannot renegotiate every agreement. But we are happy to extend to all past authors the rights laid out in the new licence agreements: to re-use the papers in any printed volume of which they are an author; to post a PDF copy on their own (not-forprofit) website; to copy (and for their institutions to copy) their papers for use in coursework teaching; and to re-use figures and tables. For the exact terms and conditions, please see a copy of the licence agreement at http://npg.nature.com/authornews.

\section{Overseas abuse of China's development}

\section{China must do more to protect the integrity of its policies that encourage greater participation by Chinese researchers overseas.}

or every billion in funds that the Chinese government pours into research, there are probably a hundred overseas researchers ready to return to take advantage of its generosity. But the investment boom aimed at strengthening China's science greatly outweighs the development of administrative infrastructure needed to monitor the system.

A petition has brought the problem to the attention of the Chinese scientific community. Critics say that overseas Chinese researchers are rapaciously gathering grants in China while reneging on agreements to spend most of their time overseeing the research projects there (see page 23). The critics, most of whom gave up positions abroad to work full-time in China, rightly want the government to act.

This will require the government to do something it is not used to doing: establish a greater rapport with a wider base of its researchers.
In other words, it needs to complement its notoriously top-down approach to scientific investment with a bottom-up element, whereby a wide range of China's researchers can give feedback to the government, not only on issues of misconduct and cheating, but also on investment priorities.

Without determined action, some researchers will continue to get big grants and big laboratories without putting in the time. The research institutions or universities that house them stand to gain from the grants' overhead contributions, and might thus tolerate abuse. But Chinese science will lose out. It will not only lose the investment, through inefficient use, but it could also lose the faith of researchers as it blurs the line between those who are running back and forth between two countries honestly trying to help China, often with little recompense, and those who are merely out for gain. 